The Israeli J ournal of Aquaculture - Bamidgeh, IJ A_69.2017.1437, 8 pages

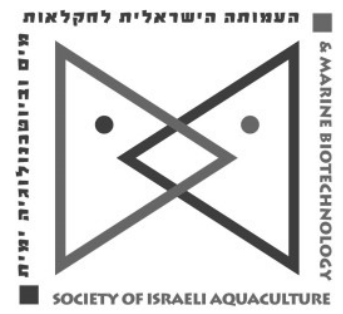

The IJ A appears exclusively as a peer-reviewed on-line open-access journal at http://www.siamb.org.il/. To read papers free of charge, please register online at registration form.

Sale of IJ A papers is strictly forbidden.

\title{
The Efficacy of Chamomile (Matricaria chamomilla) Oil as a Promising Anaesthetic Agent for Two Freshwater Aquarium Fish Species
}

\author{
Erkan CAN ${ }^{1, *}$, Volkan KI ZAK ${ }^{1}$, Esin ÖZÇIÇEK ${ }^{2}$, Şafak \\ SEYHANEYI LDI Z CAN ${ }^{3}$
}

${ }^{1}$ Fisheries Faculty, Department of Aquaculture, Munzur University, 62000, Tunceli, Turkey

${ }^{2}$ Fisheries Faculty, Department of Basic Sciences, Munzur University, 62000, Tunceli, Turkey

${ }^{3}$ Engineering Faculty, Department of Bioengineering, Munzur University, 62000, Tunceli, Turkey

Keywords: Anesthesia; chamomile; essential oil; Labidochromis caeruleus; Sciaenochromis fryeri

\begin{abstract}
The efficacy of anesthetic chamomile oil (from Matricaria chamomilla L.) was evaluated in two freshwater aquarium fish species, Electric Blue Hap (Sciaenochromis fryeri) and Yellow Princess (Labidochromis caeruleus). Fish were exposed to ten concentrations of anesthetic $(0.1,0.2,0.3,0.4$, $0.5,0.6,0.7,0.8,0.9$ and $1.0 \mathrm{ml} / \mathrm{L}$ ). The optimal concentrations identified as $0.6 \mathrm{ml} / \mathrm{L}$ for deep anesthesia (A5) for both two species. The minimal sedative concentration at the stage of loss of equilibrium (A3) was found to be $0.3 \mathrm{ml} / \mathrm{L}$. The induction time generally decreased significantly with increasing concentrations of chamomile oil for all treatment groups. Recovery time tended to increase with increased chamomile oil at concentrations lower than $0.7 \mathrm{ml} / \mathrm{L}$, but after this concentration it decreased. Chamomile oil proved to be effective as an anesthetic for both ornamental fish species. These findings suggest that chamomile oil is a promising anesthetic agent for aquaculture. However, further studies should be focused on species based investigations on the effect of temperature, transfer of fish, and their effect on antioxidant and oxidant status, in order to gather further information.
\end{abstract}

* Corresponding author. Tel: +905325493956, email: ecanengineer@gmail.com, erkancan@munzur.edu.tr 


\section{I ntroduction}

To facilitate the handling of fish without causing injury or stress requires some form of sedation or anesthesia (Summerfelt and Smith, 1990; Ross and Ross, 1999). When choosing an anesthetic, it is important to consider aspects such as efficacy, cost, availability, and ease of use, as well as toxicity to fish, humans, and their impact on the environment (Soto and Burhanuddin, 1995). Up to now, various anesthetics have been used for aquaculture (Gilderhus and Marking, 1987; Summerfelt and Smith, 1990; Stoskopf, 1993; Ross and Ross, 1999; Altun and Danabaş, 2006). The major ones are tricaine methanesulphonate (MS-222), 2-phenoxyethanol, quinaldine, and benzocaine. Studies have been conducted and have demonstrated success in employing essential oils with anesthetic properties in aquaculture; these include clove oil from Syzygium aromaticum Linn (Soto and Burhanuddin 1995; Cooke et al. 2004; Bressler and Ron, 2004; Gullian and Villanueva 2009; Pedrazzani and Neto 2016), bushy lippia oil from Lippia alba (Cunha et al. 2010), rosemary Rosmarinus officinalis oil (Ghazilou and Chenary 2011), tree basil Ocimum gratissimum oil (Silva et al. 2012), spearmint Mentha spicata oil (Roohi and Imanpoor 2015), as well as camphor Cinnamomum camphora oil, and mint Mentha arvensis oil (Pedrazzani and Neto 2016) (Table 1).

Table 1. Effective concentrations reported for some essential oils in aquaculture

\begin{tabular}{lllll}
\hline $\begin{array}{l}\text { Species for } \\
\text { anesthetic agent }\end{array}$ & Species & $\begin{array}{l}\text { Weight } \\
(\mathrm{g})\end{array}$ & $\begin{array}{l}\text { Concentration } \\
(\mu \mathrm{l} / \mathrm{L})\end{array}$ & Reference \\
\hline $\begin{array}{l}\text { Clove oil } \\
\text { (Eugenia } \\
\text { caryophylatta) }\end{array}$ & $\begin{array}{l}\text { Rainbow trout } \\
\text { (Oncorhynchus mykiss) }\end{array}$ & $20 \pm 1,25$ & $40-50$ & $\begin{array}{l}\text { Metin et al., } \\
\text { (2015) }\end{array}$ \\
\hline $\begin{array}{l}\text { Clove oil } \\
\text { (Syzygium } \\
\text { aromaticum) }\end{array}$ & $\begin{array}{l}\text { Clown Anemonefish } \\
\text { (Amphiprion ocellaris) }\end{array}$ & $0.48 \pm 0.21$ & 27 & $\begin{array}{l}\text { Pedrazzani and } \\
\text { Neto., (2016) }\end{array}$ \\
\hline $\begin{array}{l}\text { Mint oil } \\
\text { (Menta piperita) }\end{array}$ & $\begin{array}{l}\text { Rainbow trout } \\
\text { (Oncorhynchus mykiss) }\end{array}$ & $20 \pm 1,25$ & 200 & $\begin{array}{l}\text { Metin et al., } \\
\text { (2015) }\end{array}$ \\
\hline $\begin{array}{l}\text { Mint oil } \\
\text { (Mentha arvensis) }\end{array}$ & $\begin{array}{l}\text { Clown Anemonefish } \\
\text { (Amphiprion ocellaris) }\end{array}$ & $0.48 \pm 0.21$ & 70 & $\begin{array}{l}\text { Pedrazzani and } \\
\text { Neto., (2016) }\end{array}$ \\
\hline $\begin{array}{l}\text { Lavender oil } \\
\text { (Lavandula } \\
\text { angustifolia) }\end{array}$ & $\begin{array}{l}\text { Rainbow trout } \\
\text { (Oncorhynchus } \\
\text { mykiss) }\end{array}$ & $20 \pm 1,25$ & $>200$ & $\begin{array}{l}\text { Metin et al., } \\
\text { (2015) }\end{array}$ \\
\hline $\begin{array}{l}\text { Rosemarine oil } \\
\text { (Rosmarinus } \\
\text { officinalis) }\end{array}$ & $\begin{array}{l}\text { Common carp, } \\
\text { (Cyprinus carpio) }\end{array}$ & $652 \mathrm{~g} \pm 3.1$ & $250-1000$ & $\begin{array}{l}\text { Ghazilou and } \\
\text { Chenary (2011) }\end{array}$ \\
\hline $\begin{array}{l}\text { Camphor oil } \\
\text { (Cinnamomum } \\
\text { camphora) }\end{array}$ & $\begin{array}{l}\text { Clown Anemonefish } \\
\text { (Amphiprion ocellaris) }\end{array}$ & $0.48 \pm 0.21$ & 500 & $\begin{array}{l}\text { Pedrazzani and } \\
\text { Neto., (2016) }\end{array}$ \\
\hline $\begin{array}{l}\text { Lemon verbena } \\
\text { (Aloysia triphylla) }\end{array}$ & $\begin{array}{l}\text { Silver catfish } \\
\text { (Rhamdia quelen) }\end{array}$ & $2.6-3.0$ & 200 & $\begin{array}{l}\text { Parodi et al., } \\
\text { (2014) }\end{array}$ \\
\hline $\begin{array}{l}\text { Basil oil } \\
\text { (Ocimum americaum) }\end{array}$ & $\begin{array}{l}\text { Silver catfish } \\
\text { (Rhamdia quelen) }\end{array}$ & $8.09 \pm 0.22$ & $200-500$ & $\begin{array}{l}\text { Silva et al., } \\
\text { (2015) }\end{array}$ \\
\hline
\end{tabular}

The ideal anesthetic should permit a reasonable duration of exposure, produce anesthesia within $3 \mathrm{~min}$ or less, allow recovery within 5 min or less, cause no toxicity to fish at treatment levels, present no safety problems, leave low tissue residue after a withdrawal time of $1 \mathrm{~h}$ or less, and be reasonable in cost (Marking and Meyer, 1985). Additionally, correct concentration of anesthetic must ensure the survival of treated fish when exposed to anesthetic for 30 min (Chambel et al., 2015).

Chamomile is a well-known medicinal plant species from the Asteraceae family, often referred to as the "star among medicinal species." It is a highly favored and much used medicinal plant in folk and traditional medicine (Singh et al., 2011). International demand for chamomile oil has grown steadily in different areas such as food, agriculture, medicine etc. As a result, the plant is widely cultivated in Europe and 
has been introduced in some Asian countries for production of its essential oil. $M$. chamomilla L., Anthemis nobilis L. Ormenis multicaulis which belongs to the family Asteraceae is a natural major source of "blue oil" and flavonoids. The oil is used as a sedative and for digestion (Gould et al., 1973; Sharma et al. 1983) and is also antibacterial and fungicidal (Gould et al., 1973). Other properties include sedative, anti inflammatory, antiseptic, healing, carminative, and spasmolytic activity (Salamon, 1992). Chamomile is widely regarded as a mild tranquillizer and sleep-inducer. Sedative effects may be due to a flavonoid that binds to benzodiazepine receptors in the brain (Avallone et al., 1996). Compounds present in extracts of chamomile can also bind BDZ and GABA receptors in the brain and may be responsible for some sedative effect (Park et al. 1999). However, many of these compounds are as yet unidentified (Srivastata et al., 2010).

The Electric Blue Hap, Sciaenochromis fryeri, has long been a favorite among African cichlid keepers because of its intense electric blue coloring. It comes from Lake Malawi, Africa, and is found in many color morphs throughout the lake (Konings, 1993). The Yellow Princess, Labidochromis caeruleus, is a freshwater perciform fish, a cichlid, also called the electric yellow, lemon yellow lab, the blue streak hap and the electric yellow. The Yellow Princess is a bright yellow freshwater cichlid and one of the most commercially valuable aquarium fish species (Maréchal, 1991; Ergün et al., 2010).

Essential oils obtained from plants such as clove, mint, rosemary, lemon verbena, lavender have been studied, however oils from chamomile have not. Thus, the aim of present study was to investigate efficacy and determine the optimum concentration of the chamomile oil as a new anesthetic agent for two ornamental fish species Sciaenochromis fryeri, and Labidochromis caeruleus.

\section{Material and Methods}

Experimental layout. Experiments were conducted on S. fryeri (mean length $4.29 \pm$ $0.14 \mathrm{~cm}$, mean body weight $1.13 \pm 0.12 \mathrm{~g}$ ) and on L. caeruleus (mean length $3.9 \pm$ $0.13 \mathrm{~cm}$, mean body weight $1.02 \pm 0.12 \mathrm{~g}$ ). Fish were stocked in separate $160 \mathrm{~L}$ glass aquaria, water temperature $25^{\circ} \mathrm{C}$, and $\mathrm{pH} 7.84$, with an inner filter, and fed ad libitum once daily with granulate commercial feed containing $42.5 \%$ crude protein, $10.3 \%$ crude fat, $2.8 \%$ fibre, $5 \%$ moisture and $4.9 \%$ crude ash (Sera Granured, Germany). All the fish were starved for $24 \mathrm{~h}$ prior to the experiment (Weyl et al., 1996) which was conducted at the Laboratory of Bioengineering Department, Munzur University Engineering Faculty in Turkey.

Anesthethic agent and GC Analysis. Chamomile oil (Matricaria chamomilla L.) was obtained from a commercial company (Defne Doga, Turkey). The EO was obtained from fresh leaves using the hydrodistillation process with a Clevenger type apparatus (European Pharmacopoeia, 2007). The essential oil component was analyzed at the Ege University Drug Development and Pharmacokinetic Research Center (ARGEFAR).

GC-MS TIC analysis was performed using an Agilent-6890 gas chromatograph coupled with an Agilent 5973 mass selective detector under the following conditions: HP innovax column (1:100 hegzane, $60 \mathrm{~m} \times 0.32 \mathrm{~mm} \times 0.25 \mu \mathrm{m})$; split inlet $1: 100$; Databank NIST 2002 and ARGEFAR. The constituents of the chamomile oil were identified by comparing their mass spectra with a mass spectral library (NIST, 2002). Results are shown in Table 2. 
Table 2. Compounds of chamomile essential oil used in the study

\begin{tabular}{lc}
\hline \multicolumn{2}{c}{ Essential Oil Analysis of Chamomile } \\
\hline Compounds & Result (\% Area) \\
\hline Linalool & 8.40 \\
Alpha terpinenyl acetate & 1.65 \\
Benzyl acetate & 4.34 \\
Geranyl acetate & 4.05 \\
Beta citronellol & 3.70 \\
1.1 oxbis 2-propanol & 7.35 \\
Geraniol & 10.04 \\
Alpha ionone & 5.65 \\
3.3 oxybis 2-buthanol & 3.62 \\
Benzenethanol & 6.40 \\
Hidroxycitronellal & 4.47 \\
Anisaldehyde & 1.47 \\
Alpha bisabolol oxide & 28.53 \\
Anisaldehyde propylene glycol acetal & 6.05 \\
Unidentified & 4.28 \\
\hline
\end{tabular}

Experimental design. Ten different concentrations of the chamomile oil were $0.1,0.2,0.3,0.4,0.5,0.6,0.7,0.8,0.9$ and $1.0 \mathrm{ml} / \mathrm{L}(\mathrm{N}=6$ for each group) after a pre-treatment trial. All treatments were conducted in triplicate. The determination of induction $(A)$ and recovery $(R)$ stages after anesthesia were modified from Summerfelt and Smith (1990); Keene et al. (1998). See Table 3.

Table 3. Anesthesia stages in the present study (modified from Summerfelt and Smith 1990; Keene et al., 1998; Mylonas et al., 2005)

\begin{tabular}{|c|c|c|}
\hline Phase & Code & Fish Behavior Characteristics \\
\hline \multicolumn{3}{|l|}{ Induction } \\
\hline $\begin{array}{l}\text { Total loss of } \\
\text { equilibrium }\end{array}$ & A3 & $\begin{array}{l}\text { Total loss of equilibrium (first occurrence), regular } \\
\text { opercular movement, pectoral fins moving }\end{array}$ \\
\hline Deep anesthesia & A5 & $\begin{array}{l}\text { No reflex, opercular movements irregular and slow, no } \\
\text { response to strong external stimulus, pectoral fin } \\
\text { movements depend on the opercular movement or no } \\
\text { movement }\end{array}$ \\
\hline \multicolumn{3}{|l|}{ Recovery } \\
\hline $\begin{array}{l}\text { Total recovery of } \\
\text { equilibrium }\end{array}$ & R1 & Total recovery of equilibrium, swimming erratic at onset \\
\hline $\begin{array}{l}\text { Total behavioral } \\
\text { recovery }\end{array}$ & R3 & Normal Swimming began, responsiveness to visual stimuli \\
\hline
\end{tabular}

The anesthetic effects were recorded by seconds. Different concentrations of chamomile oil previously dissolved in ethanol 95\% ethanol (at a rate of 1:10). Once stage A5 was reached, the fish were removed, weighed, and placed individually in a recovery aquarium within $<1 \mathrm{~min}$. When reaching stage A5 exceeded $5 \mathrm{~min}$ the observations were discontinued. Induction and recovery times were recorded to the nearest second using an electronic stop-watch (Mylonas et al., 2005). Once recovered, fish were transferred into stock aquariums, and were monitored for survival and abnormal behavior for the following 24 hours. The control groups contained only ethanol at a concentration that was equivalent to the highest concentration used in the experimental conditions $(10 \mathrm{ml} / \mathrm{L}$ ) and were observed for $5 \mathrm{~min}$. (Adapted from Mylonas et al., 2005). The chosen concentrations are based on preliminary tests.

Reliability test for optimal anesthetic concentration. The reliability test is important because the duration of exposure should always be kept within an adequate margin of safety since practical situations often involve anesthesia of a large number of fish in one tank. To identify optimal concentrations of anesthetic, fish were exposed for 30 min at a concentration of $0.6 \mathrm{ml} / \mathrm{L}$ (adapted from Chambel et al., 2015). 
Statistical analysis. Prior to testing, normality and homogeneity of data were checked to comply with the assumptions of ANOVA. Significant differences between concentrations of chamomile oil were determined by one-way ANOVA followed by the Duncan Multiple Range test. Statistically significant differences are expressed as $p<0.05$. Analysis of data was carried out using SPSS 15.0. The results are presented as means \pm standard error (standard error of the mean, SEM).

\section{Results}

Induction and recovery. To determine the efficacy of each concentration of chamomile oil, induction times (as A3 and A5) and recovery times (as R3 and R5) were observed. Induction times of anesthesia varied with anesthetic concentrations, decreasing with the increase of chamomile oil concentrations. Recovery time tended to increase with the increase of the chamomile oil concentration at lower concentrations than $0.7 \mathrm{ml} / \mathrm{L}$, but at upper concentrations of $0.7 \mathrm{ml} / \mathrm{L}$ it decreased. The concentration of $0.6 \mathrm{ml} / \mathrm{L}$ was found to be the correct concentration for both cichlid species. At the concentration of $0.1-0.2 \mathrm{ml} / \mathrm{L}$, fish in all the groups maintained their equilibrium while fish exposed to 0.3 and $0.4 \mathrm{ml} / \mathrm{L}$ of chamomile oil reached the A3 stage. Deep anesthesia (A5) was induced at a more rapid rate at higher concentrations of anesthetic than $0.4 \mathrm{ml} / \mathrm{L}$ for all fish $(p<0.05)$ (Tables $4 \& 5)$.

Table 4. The timing of anesthesia phases at different concentrations of chamomile oil for the Electric Blue Hap (Sciaenochromis fryeri)

\begin{tabular}{|c|c|c|c|c|}
\hline \multirow{2}{*}{$\begin{array}{l}\text { Concentration } \\
(\mathrm{ml} / \mathrm{L})\end{array}$} & \multicolumn{2}{|c|}{ Induction Time (sec) } & \multicolumn{2}{|c|}{ Recovery Time (sec) } \\
\hline & A3 & A5 & R1 & R3 \\
\hline 0.1 & n.o. & n.o. & n.t. & n.t. \\
\hline 0.2 & n.o. & n.o. & n.t. & n.t. \\
\hline 0.3 & $174 \pm 13.52 a$ & n.o. & n.t. & n.t. \\
\hline 0.4 & $163 \pm 10.33^{a}$ & n.o. & n.t. & n.t. \\
\hline 0.5 & $155 \pm 8.61$ & $210 \pm 5.41^{a}$ & $155 \pm 7.65 a b$ & $190 \pm 10.01^{a}$ \\
\hline 0.6 & $114 \pm 6.11^{b}$ & $168 \pm 9.12 b$ & $140 \pm 7.22^{a}$ & $173 \pm 9.06^{a}$ \\
\hline 0.7 & $105 \pm 8.61 b c$ & $140 \pm 5.91 \mathrm{c}$ & $170 \pm 8.13 b$ & $283 \pm 10.23 b$ \\
\hline 0.8 & $99 \pm 4.14^{c}$ & $112 \pm 8.61^{d}$ & $160 \pm 8.61^{a b}$ & $230 \pm 8.61^{c}$ \\
\hline 0.9 & $80 \pm 3.88^{d}$ & $125 \pm 7.25 \mathrm{~d}$ & $140 \pm 8.44^{a}$ & $175 \pm 8.31^{a}$ \\
\hline 1.0 & $50 \pm 7.98$ e & $60 \pm 6.45^{\mathrm{e}}$ & $95 \pm 9.11^{c}$ & $150 \pm 5.03 \mathrm{~d}$ \\
\hline
\end{tabular}

*Values (mean \pm SE) with different superscripts within the same column are significantly different $(p<0.05)$.

n.o. indicates the phase was not observed

n.t. indicates fish were not treated

The shortest time for both induction (A5) and recovery (R3) occurred at the same concentration $(1.0 \mathrm{ml} / \mathrm{L})$ at $60 \pm 6.45 \mathrm{sec}$ and $90 \pm 5.46 \mathrm{sec}$, respectively. However, the highest induction time for A5 stage was observed at the concentration of $0.6 \mathrm{ml} / \mathrm{L}$ $(240 \pm 9.56 \mathrm{sec})$ while the highest recovery time for R3 stage was seen at the concentration of $0.7 \mathrm{ml} / \mathrm{L}(283 \pm 10.23 \mathrm{sec})$.

No mortality occurred in all treated groups during the anesthetic exposure and during observation of 24 hours after exposure. Tables $4 \& 5$ present the results of induction and recovery times of Sciaenochromis fryeri and Labidochromis caeruleus, exposed to different concentrations of chamomile oil. 
Table 5. The timing of anesthesia stage at different concentrations of chamomile oil for Yellow Princess (Labidochromis caeruleus)

\begin{tabular}{|c|c|c|c|c|}
\hline \multirow{2}{*}{$\begin{array}{l}\text { Concentration } \\
(\mathrm{ml} / \mathrm{L}) \text {. }\end{array}$} & \multicolumn{2}{|c|}{ Induction Time (sec) } & \multicolumn{2}{|c|}{ Recovery Time (sec) } \\
\hline & A3 & A5 & R1 & R3 \\
\hline 0.1 & n.o. & n.o. & n.t. & n.t. \\
\hline $0 . \overline{2}$ & n.o. & n.o. & n.t. & n.t. \\
\hline 0.3 & $183 \pm 12.08^{a}$ & n.o. & n.t. & n.t. \\
\hline 0.4 & $175 \pm 9.11$ & n.o. & n.t. & n.t. \\
\hline 0.5 & $135+8.21 b b$ & $240+9.56^{a}$ & $135+7.01 \mathrm{a}$ & $178+8.86^{a}$ \\
\hline 0.6 & $118+6.44 b c$ & $172+9.12 b$ & $100+7.32 b$ & $150+10.23 b$ \\
\hline 0.7 & $115 \pm 6.66^{c}$ & $160 \pm 8.11 b$ & $150 \pm 5.69 c$ & $202 \pm 12.03 c$ \\
\hline 0.8 & $110 \pm 9.21 \mathrm{c}$ & $123 \pm 8.99$ & $200 \pm 11.12 \mathrm{~d}$ & $245 \pm 14.33 d$ \\
\hline 0.9 & $100 \pm 6.51 \mathrm{c}$ & $120 \pm 9.39 c$ & $125 \pm 8.64^{a}$ & $160 \pm 9.79^{a}$ \\
\hline 1.0 & $48 \pm 7.65^{d}$ & $61 \pm 8.11 \mathrm{~d}$ & $65 \pm 3.92 \mathrm{e}$ & $90 \pm 5.46^{\mathrm{e}}$ \\
\hline
\end{tabular}

*Values (mean \pm SE) with different superscripts within the same column are significantly different $(p<0.05)$.

n.o. indicates the phase was not observed

n.t. indicates fish were not treated

The reliability test. Additionally, fish were exposed to anesthetic for $30 \mathrm{~min}$ at a concentration of $0.6 \mathrm{ml} / \mathrm{L}$. No death was observed either during the treatment, or after observation of 24 hours.

In the control, the exposure of the two ornamental fish species to ethanol (i.e., the anesthetic solvent) did not induce anesthesia, or any apparent modifications in the behavior of the fish. The concentration of ethanol used in the study had no effect on the fish at maximum exposure time of this study ( $10 \mathrm{ml}$ for $5 \mathrm{~min}$ ).

\section{Discussion}

An ideal anesthetic should produce anesthesia rapidly (e.g., less than $3 \mathrm{~min}$ ), allow for speedy recovery, should not be toxic to fish and users, leave low tissue residues, and be inexpensive (Marking and Meyer, 1985). According to these criteria, the optimal identified concentration was $0.6 \mathrm{ml} / \mathrm{L}$ for both cichlid species. In addition, we observed that recovery times are related to the anesthetic concentration. The induction time generally decreased significantly with increasing concentrations of chamomile oil for all species studied (Tables $4 \& 5$ ). Recovery time was positively correlated with concentration of anesthetic (Weyl et al. 1996; Mylonas et al., 2005). Interestingly, when concentration was greater than $0.7 \mathrm{ml} / \mathrm{L}$, recovery time decreased in both fish species studied. Recovery time increased with increasing concentrations of MS-222 for three ornamental fish species, D. rerio, P. reticulata, and S. discus while recovery time decreased with increasing concentrations of the same anesthetic in another species, $X$. helleri (Chambel, et al., 2015). A possible explanation for these results is probably related to the fact that increasing concentrations are also associated with a shorter time of contact between fish and the anesthetic and a lower uptake of the anesthetic agent (Chambel, et al., 2015). Thus, during recovery, the anesthetic is cleared more rapidly from the bloodstream (Weber et al. 2009; Chambel, et al., 2015). However, the molecular characteristics of the anesthetics, as well as the physiological and metabolic characteristics probably affect recovery time as well (Chambel, et al., 2015). Therefore, chamomile oil proved to be effective as anesthesia, and safe for both ornamental fish species.

A correct concentration of anesthetic for fish should allow fish to survive for $30 \mathrm{~min}$ after being applied (Chambel et al., 2015). In our study the fish did not die when treated with an optimal concentration of anesthetic, and reacted favorably after $30 \mathrm{~min}$ induction. The reliability test is particularly important and relevant because in practice, anesthesia involves a large number of fish in one tank and their exposure beyond these limits can result in major mortalities (Chambel et al., 2015).

"The ideal anesthetic should permit a reasonable duration of exposure, produce anesthesia within 3 min or less, allow recovery within 5 min or less, cause no toxicity to fish at treatment levels, present no mammalian safety problems, leave low tissue residues after a withdrawal time of $1 \mathrm{~h}$ or less, and be reasonable in cost" (Marking and Meyer 1985). We also claim that "the anesthetic is conceived acceptable if it has a good smell and is also environmental friendly for aquaculture" as reported in anesthetic experiments for two other herbal essential oil, Eucalyptus sp. and Origanium 
sp. (Bodur et al., 2018).

Our findings suggest that chamomile oil (from M. chamomilla L.) is a promising anesthetic agent for aquaculture. However, further studies are needed to establish its effect on fish of different sizes, held in different temperatures.

\section{Acknowledgments}

We thank Gökce YILMAZ, the staff of Defne doga for most efficient technical support.

\section{References}

Altun T, and D. Danabaş, 2006. Effects of short and long exposure to the anesthetic 2- phenoxyethanol mixed with ethyl alcohol on common carp (Cyprinus carpio L., 1758) fingerlings. Isr J Aquacult-Bamid, 58: 178- 182.

Avallone R., Zanoli P., Corsi L., Cannazza G. and Baraldi M, 1996. Benzodiazepine compounds and GABA in flower heads of Matricaria chamomilla. Phytotherapy Res, 10: 177-179.

Bressler and Ron, 2004. Effect of anasthetics on stress and the innate system of gilthead seabream (Sparus auratus). Isr J Aquacult-Bamid, 56(1), 5-13.

Bodur T, Afonso J M, Montero D, Navarro, A., 2018. Assessment of effective dose of new herbal anesthetics in two marine aquaculture species: Dicentrarchus labrax and Argyrosomus regius, Aquaculture, 482: 78-82.

Chambel, J., Pinho, R., Sousa, R., Ferreira, T., Baptista, T., Severiano, V., Mendes, S. and R. Pedrosa, 2015. The efficacy of MS-222 as anaesthetic agent in four freshwater aquarium fish species. Aquac Res, 46: 1582-1589. doi: 10.1111 /are.12308.

Cooke S.J., Suski C.D., Ostrand KG., Tufts B.L., and D.H. Wahl, 2004. Behavioral and physiological assessment of low concentrations of clove oil anaesthetic for handling and transporting largemouth bass (Micropterus salmoides). Aquaculture, 239: 509529.

Cunha M.A., Barros F.M.C., Garcia L.O., Veeck A.P.L., Heinzmann B.M., Loro V.L., Emanuelli T., and B. Baldisserotto, 2010. Essential oil of Lippia alba: a new anesthetic for silver catfish (Rhamdia quelen). Aquaculture, 306: 403-406.

Ergün S., Guroy D., Tekesoglu H., Guroy B., Celic I., Tekinay A.A., and M. Bulut, 2010. Optimum dietary protein level for Blue Streak Hap, Labidochromis caeruleus. Turkish J Fish Aquat Sci, 10: 27-31.

European Pharmacopoeia (6th edn) 2007. European Directorate for the Quality of Medicines, Strassbourg, France. 4392 p.

Ghazilou A. and F. Chenary, 2011. Evaluation of rosemary oil anesthesia in carp. J Vet Res 15: 112-118.

Gilderhus P.A. and L.L. Marking, 1987. Comparative efficacy of 16 anesthetic chemicals on rainbow trout. North Am J Fish Manage, 7: 288- 292.

Gould L., Reddy C.V. and F.F. Compreht, 1973. Cardiac effect of chamomile tea. J Clin Pharmacol, 13: 475-9.

Gullian M. and J. Villanueva, 2009. Efficacy of tricaine methanesulphonate and clove oil as anaesthetics for juvenile cobia Rachycentron canadum. Aquac Res, 40: 852-860.

Keene J.L., Noakes D.L.G., Moccia R.D. and C.G. Soto, 1998. The efficacy of clove as an anaesthetic for rainbow trout, Oncorhynchus mykiss (Walbaum). Aquac Res, 29: 89- 101.

Konings A., 1993. Malawian cichlids: a revision of the genus Sciaenochromis Eccles \& Trewavas, 1989 (Pisces, Cichlidae). The Cichlids Yearbook 3, 28-36.

Maréchal C., 1991. Labidochromis. p. 210-217. In J. Daget, J.-P. Gosse, G.G. Teugels D.F.E. Thys van den Audenaerde (eds.) Check-list of the freshwater fishes of Africa (CLOFFA). ISNB, Brussels; MRAC, Tervuren; and ORSTOM, Paris. Vol. 4. 
Marking L.L and F.P. Meyer, 1985. Are Better Anesthetics Needed in Fisheries. Fisheries. 10: 2-5.

Mylonas C.C. Cardinaletti G. Sigelaki I. and A. Polzonetti-Magni, 2005. Comparative efficacy of clove oil and 2-phenoxyethanol as anesthetics in the aquaculture of European sea bass (Dicentrarchus labrax) and gilthead sea bream (Sparus aurata) at different temperatures. Aquaculture, 246 , 467-481

Metin S., Didinen B.I., Kubilay A., Pala M. and Aker İ., 2015. Bazı Tıbbi Bitkilerin Gökkuşağı Alabalıkları (Oncorhynchus mykiss Walbaum, 1792) Üzerinde Anestezik Etkilerinin Belirlenmesi. LimnoFish, 1: 37-42.

NIST 2002. NIST/EPA/NIH mass spectral library and search/analysis programs. J. Wiley and Sons, Hoboken, NJ. 2002.

Park I.S., Park M.O. Hur, J., Paladini A.C, Marder M., Viola H. Wolfman C., Wasowski C., and J.H. Medina, 1999. Flavonoids and the central nervous system: from forgotten factors to potent anxiolytic compounds. J Pharm Pharmacol, 51(5): 519-26.

Parodi T.V., Cunha M.A., Becker A.G., Zeppenfeld C.C., Martins D.I., Koakoski G., Barcellos L.G., Heinzmann B.M. and B. Baldisserotto, 2014. Anesthetic activity of the essential oil of Aloysia triphylla and effectiveness in reducing stress during transport of albino and gray strains of silver catfish, Rhamdia quelen Fish Physiol Biochem, 40: 323-334.

Pedrazzani A.S., and A.O. Neto, 2016, The anaesthetic effect of camphor (Cinnamomum camphora), clove (Syzygium aromaticum) and mint (Mentha arvensis) essential oils on clown anemonefish, Amphiprion ocellaris (Cuvier 1830), Aquac Res, 47: 769-776.

Ross L.G. and B. Ross 1999. Anaesthetic and Sedative Techniques for Aquatic Animals. Blackwell Science Ltd., London. $159 \mathrm{pp}$.

Roohi Z. and M.R. I manpoor, 2015. The efficacy of the oils of spearmint and methyl salicylate as new anesthetics and their effect on glucose levels in common carp (Cyprinus carpio L., 1758) juveniles, Aquaculture, 437: 327-332.

Srivastata J.K., Shankar E. and S. Gupta, 2010. Chamomile: a herbal medicine of the past with bright future, Mol Med Rep, 3: 895-901.

Salamon I., 1992. Chamomile a medicinal plant. J Herbs Spices Med Plants, 10: 1-4.

Sharma, A., Kumar, A., and O.P. Virmani, 1983. Cultivations of German chamomile - a review. Curr Res Med Aromat Plants 5: 269-78.

Silva L.L. Garlet Q.i், Koakoski G., Abreu M.S., Mallmann C.A., Baldisserotto B., Barcellos L.J.S. and B.M. Heinzmann, 2015. Anesthetic activity of the essential oil of Ocimum americanum in Rhamdia quelen (Quoy \& Gaimard, 1824) and its effects on stress parameters. Neotrop I chthyol 13:715-722.

Silva L.L., Parodi T.V., Reckziegel P., Garcia V.O., Burger M.E., Baldisserotto B., Malmann C.A., Pereira A.M.S. and B.M. Heinzmann, 2012. Essential oil of Ocimum gratissimum: anesthetic effect, mechanism of action and tolerance in silver catfish (Rhamdia quelen). Aquaculture, 350-353:91-97.

Singh O., Khanam Z., Misra N., and M.K. Srivastava, 2011. Chamomile (Matricaria chamomilla L.): An overview. Pharmacogn Rev 5(9), 82-95.

Soto, C.G. and G. Burhanuddin, 1995. Clove oil as a fish anaesthetic for measuring length and weight of rabbitfish (Siganus lineatus). Aquaculture, 135: 149-152.

Stoskopf, M., 1993. Anaesthesia. In: Brown, L. (Ed.), Aquaculture for Veterinarians. Pergamon Press, Oxford, pp. 161- 167.

Summerfelt, R.C. and L.S. Smith, 1990. Anaesthesia, surgery and related techniques. In: Schreck, C.B., Moyle, P.B. (Eds.), Methods in Fish Biology. American Fisheries Society, Bethesda, pp. 213- 272.

Weber R.A., Peleteiro J.B., Mart_In L.O.G. and M. Aldegunde, 2009. The efficacy of 2-phenoxyethanol, metomidate, clove oil and MS-222 as anaesthetic agents in the Senegalese sole (Solea senegalensis Kaup 1858). Aquaculture, 288: 147-150.

Weyl O., Kaiser H. and T. Hecht, 1996. On the efficacy and mode of action of 2phenoxyethanol as an anaesthetic for goldfish (Carassius auratus), at different temperatures and concentrations. Aquac Res 27: 757-764. 